ISSN No. 0974-035X

An indexed refereed \& peer-reviewed journal of higher education

Towards Excellence

UGC-HUMAN RESOURCE DEVELOPMENT CENTRE

Gujarat University, Ahmedabad-380009, Gujarat, India

\title{
OUTCOME BASED CURRICULUM DESIGNING: A FUTURISTIC APPROACH THE CASE STUDY OF THE MAHARAJA SAYAJIRAO UNIVERSITY OF BARODA
}

\author{
Prof Hitesh D Raviya \\ Ms. Deepali Dinesh Shahdadpuri
}

\begin{abstract}
In the earlier days, syllabi were designed by some experienced teachers or experts who got specialization in particular areas in all the education institutions. The students were graded on the marks scored in the assessment in which some students might score high and some might not be. This type of previous curriculum did not ensure what students need to learn or what they are learning in their classrooms. University Grant Commission (UGC) under MHRD, Government of India, has already submitted the final draft under "Quality Improvement Programme, 2018" aim at the development of "Learning Outcomes Based Curriculum Framework (LOCF)" at UG and PG Levels. The learning outcomes are designed to help students understand the objectives of the course provided to them. It is a framework based on the expected learning outcomes (such as disciplinary knowledge, communication skills, critical thinking, problem-solving, analytical reasoning, research-related skills, etc.) that are expected to be attained by the students at the completion of their graduation. In this research paper, the researcher attempts to elaborate about Curriculum designing based on the approaches provided by J.C. Richards and Learning-Outcomes based Curriculum Framework. This research paper also has taken into consideration the analysis of curriculum development for the subject offered by Department of English in Faculty of Commerce at first year undergraduate courses (UG Level) from the academic year 1979-80 till 2019-20.
\end{abstract}

Keywords: Curriculum Framework, Outcome Based Curriculum Design, Employability Skills

"The English language has been an elevating influence in our lives, Raising our standards and broadening our outlook.” -The Maharaja Sayajirao Gaekwad III 


\section{Introduction}

From Macaulay to Mahatma Gandhi, English has played a vital role in the lives of Indians during the British rule and still continues to expand its roots not only in India but all over the world as Lingua Franca. Thomas Babington Macaulay laid the foundations of English Education in India through his "Minutes" of 1835. He successfully anglicised the Indian-ness of India as a British Colony: "A class of persons Indian in blood and colour, but "English in tastes, in opinions, in moral and in intellect." Since then, a lot of focus has been given on the development of curriculum design for the development of English Language Skills at all levels of education. Curriculum is "a programme of study at educational institutions, usually consisting of a group of related subjects". Syllabus is a part of curriculum; it is "a description of the contents of a course of instruction and the order in which they are to be taught". It is perceived to be a set of course offered to the learners to acquire specific knowledge. Curriculum design is a systematic plan which summarizes the contents to be learned by the students.

Curriculum Design plays an important role in developing students' language skills emphasising the phrase, "Well planned is half done". Curriculum design offers a 'blueprint' to teachers as well as students offering objectives, implementation plan and the possible outcomes by the end of a specific course. "It takes content and shapes it into a plan for how to conduct effective teaching and learning."

Curriculum designing can be better comprehended and executed on thoughtful analysis of the approaches adopted. With 'process', 'input' and 'output', Jack C. Richards in 2013 in his research work "Curriculum Approaches in Language Teaching: Forward, Central and Backward Design" proposed three possible approaches of curriculum design i.e. 'The Forward Design', 'The Central Design' and 'The Backward Design'. 
Towards Excellence: An Indexed, Refereed \& Peer Reviewed Journal of Higher Education / Prof. Hitesh Raviya \& Ms. Deepali Shahdadpuri / Page 544-555

\begin{tabular}{|c|c|c|}
\hline The Forward Design & CONTENT $\Longrightarrow$ PROCESS $\Longrightarrow$ OUTPUT & $\begin{array}{l}\text { A traditional process where } \\
\text { the instructor decides a } \\
\text { topic for the learners, } \\
\text { chooses the materials and } \\
\text { resources, and students are } \\
\text { given tests to mark the } \\
\text { possible outcomes. }\end{array}$ \\
\hline The Central Design & $\begin{array}{l}\text { CONTENT } \\
\text { OUTPUT }\end{array}$ & $\begin{array}{l}\text { It begins with the selection } \\
\text { of materials, resources and } \\
\text { teaching methods which } \\
\text { teachers are going to use in } \\
\text { the class instead of } \\
\text { deciding the contents for } \\
\text { the learners or any possible } \\
\text { learning outcomes. Issues } \\
\text { related to 'output' can be } \\
\text { resolved during teaching } \\
\text { process itself. Thus, it gives } \\
\text { less importance to syllabus } \\
\text { design and more on } \\
\text { teaching methodology and } \\
\text { learning process, leading to } \\
\text { learners being 'active } \\
\text { participants' while } \\
\text { learning. "It emphasizes the } \\
\text { role of the teacher in } \\
\text { creating his or her own } \\
\text { curriculum in the } \\
\text { classroom". }\end{array}$ \\
\hline & & $\begin{array}{l}\text { It begins with a description } \\
\text { of the possible outcomes } \\
\text { that are to attain by the }\end{array}$ \\
\hline
\end{tabular}




\begin{tabular}{|l|l|l|}
\hline \multirow{1}{*}{ The Backward Design } & OUTPUT CONTENT & $\begin{array}{l}\text { learners at the end of a } \\
\text { specific course. It's a } \\
\text { seven-stage process } \\
\text { including: } \\
1 \text { - Diagnosis of needs } \\
\text { 2- Formulation of } \\
\text { objectives } \\
\text { 3- Selection of content } \\
\text { 4- Organisation of content } \\
\text { 5- Selection of learning } \\
\text { experiences } \\
\text { 6- Organisation of learning } \\
\text { experiences } \\
\text { 7- Determination of what to } \\
\text { evaluate and of the ways of } \\
\text { doing it. }\end{array}$ \\
\hline
\end{tabular}

The significance of syllabus design is ascertained in catering to the needs of the learners and identifying the possible learning outcomes, then planning of instructions and learning process.

Learning outcome based curriculum designing gets problematized owing to the issues and challenges the cause and effect of which is reflected in teaching and learning of English in the institutionalised apparatus. Marginalisation of English in the professional and vocational courses, differences in policy and ideologies of the government apparatus, centralised and top-down approach of the decision makers in the departments, the heterogeneity of the classrooms, the in/adeptness of the teachers and faculty members in designing and implementing of the curriculum are some of the issues and challenges contributing to the skill gap. "Despite an emphasis on active and learnercentred teaching methods in the curriculum, most of the teaching practices are still teacher-centred or follows Chalk-and-talk drill methods.” (A. Rahman, 2014: 04).

One cannot ignore the fact that learners of English in India come from heterogeneous backgrounds differentiated by language, education, medium of instruction and examination, socio-economic categories as well. The stratification of class, financial bearings, exposure to education are some of 
the determinants that contribute to the cause and need of learning English. To a certain extent these factors can also be the impediments in the journey of learning English despite being aware that English is the language of opportunity. The vicious cycle governed by these factors creates a divideof haves and have nots which gets reflected in the heterogeneous classrooms. Thus, a plausibly perfect 'blueprint' of the curriculum addressing the practical and ground realities seems to be a distant thought. .

The over emphasis on teaching of grammar and writing skills while developing the syllabus of 'English Language Skills' leading to rote learning further creates a psychological block and aversion to speaking of English, believing that learning of grammar is synonymous to learning of English, and in this process the two primary skills listening and Speaking that contribute the most in acquiring any language get neglected. The undergraduate students of various faculties are not able to communicate in English very effectively. The curriculum used at the Undergraduate Level in Foundation Courses in English in the universities of India as well as the low performance of the students in English has been a major subject of concern. It is observed that the curriculum is heavily loaded towards testing memory rather than equipping the learners with effective communication skills.

Thinkers like Mahatma Gandhi, Morarji Desai and Manubhai Pancholi laid emphasis on teaching and learning in mother tongue rather than in English. Karthik Venkatesh in an the article "Mahatma Gandhi and Language Games" states, "English, in his (Mahatma Gandhi) view, could function as the language of international communication but was a blot on the Indian character, to the extent that later in life he tersely stated in one of his writings that "it is we, the English-knowing Indians, that have enslaved India".”

Government of Gujarat has been taking constructive steps addressing the changing dynamics of employability in the globalised market based economy and bridging the industry-academia divide when it comes to enhancement of language and communication skills among the youth of Gujarat. In the last several years, the office of the Commissioner of Higher Education, Government of Gujarat has initiated three different programmes to improve the expertise of English language among the students of Gujarat, namely DELL (Digital English Language Laboratory), SCOPE (The Society for Creation of Opportunity through Proficiency in English) and KMPF (Knowledge Management Programme for Faculty). DELL is an English Language Laboratory which helps to improve not only grammar and vocabulary but also lays emphasis on professional skills and soft skills. SCOPE, which 
was established in 2007, in Gujarat, to inculcate competencies in English language in order to enhance the employability of the learners. KMPF is a program for teachers to develop the knowledge in computer and internet for research and teaching.

\section{Review of Related Literature}

Jack C. Richards in "Curriculum Approaches in Language Teaching: Forward, Central and Backward Design" (2013) describes the dimensions of the curriculum. They are input, syllabus, process, methodology, output and learning outcomes. Designing a curriculum starts with 'input' as what contents learners are going to learn and “syllabus are made” (Richards 2013:7). 'Methodology' is stage where the syllabus is put in use for teaching and learning processes which lead to outcomes or we can say the 'learning outcomes'.

Z.A. Jafre and Rany Sam in their research work on "Factors Causes Students Low English Language Learning" in English in Education (2013) discuss some factors that may be responsible for low performance of the students while learning English and communicating in English such as English teachers are "not well-trained" (Jafre, 2013). Students lack confidence to use English because they are afraid of mistakes and shy feeling. The curriculum is inappropriate for helping students to improve their English proficiency. Therefore, restricting the syllabus is the strong need for the educational institutions today.

Sheba R. Dayal's research work "English Language Learning in the ESP Context: An Indian Experiment" (2005) explores that many students lack proficiency in communication skills in English. Aparna Rao Nanduri's Ph.D. Thesis Curriculum and Methodological issues of Business Communication in Management Institutions (2012) in her exploratory and descriptive research attempts to discuss the issues faced by students after the changes has been done in the curriculum.

Nitesh Kantilal Solanki's Thesis “FROM MACAULAY TO MAHATMA GANDHI: A HISTORICAL PRESPRCTIVE OF THE TEACHING OF ENGLISH LANGUAGE AND THE GROWTH OF INDIAN WRITING IN ENGLISH UND ER THE BRITISH RULE IN INDIA" elaborates the introduction to English Education in India through the "Minutes" by Thomas Babington Macaulay in 1835 and how our country responded to the arrival of a new language in the midst of "Swadeshi" Policy introduced by Mahatma Gandhi. 
Paresh Joshi's Ph.D. Thesis "STRATEGIES FOR REDUCING MTI IN GUJARATI LEARNERS OF ENGLISH FOR ATTAINING INTERNATIONAL INTELLIGIBILITY” discusses the emergence of English and its present state in Gujarat. It describes how the globalization leads to the growing demand of English as language as it is a Lingua Franca. It investigates two major issues i.e. "reduction of Mother Tongue Inference (MTI) of Gujarati learners of English and International Intelligibility (II) in English" (Page 31).

The literature review reveals the fact that though the teaching and learning of English in India has evolved historically, need based curriculum designing is still in its infancy in India. Foregrounded in these critical revelations the research aims to study the pattern of curriculum designing from 1979 till date in the Faculty of Commerce, The Maharaja Sayajirao University of Baroda, record and analyse the curriculum of subjects offered by the Department of English at the undergraduate level. Further, the research aims to address the question- how curriculum designing has gone through a paradigm shift in Gujarat leaving an impact on the changing dynamics of higher education in context of the employability skills catering to the globalised market based economy as a case study of the Maharaja Sayajirao University of Baroda, the findings of which can be further implemented for futuristic decisions.

\section{A Case Study of the Maharaja Sayajirao University of Baroda}

"The Department of English is as old as the Maharaja Sayajirao University of Baroda (1949) and owes the genesis to the Baroda College (1881). The Department of English is at the forefront of innovative and challenging courses in English Studies." The Department of English of the Maharaja Sayajirao University of Baroda has been one of the leading contributors in shaping English Studies in Western India.

The Maharaja Sayajirao University of Baroda has that freedom to design and to implement its own curriculum because of its special and unique identity. With rise in the need of effective communication skills in English for the job market today in the field of Commerce, the university has been constantly trying to provide the skills that the students need for employment through its curriculum and syllabi development. This research paper has taken into consideration the analysis of curriculum development for the subject offered by Department of English in Faculty of Commerce at 
first year undergraduate courses (UG Level) from the academic year 1979-80 till 2019-20. This time span is chosen as it highlights and addresses the pre-economic reforms, the period liberalisation, privatisation and globalisation and also the information and technological revolution.

\begin{tabular}{|c|c|c|c|}
\hline $\begin{array}{l}\text { Sr. } \\
\text { No. }\end{array}$ & Academic Year & Title of the Course & $\begin{array}{l}\text { Key Features \& Emphasis } \\
\text { (EFL/ESP/Communication } \\
\text { Skills) }\end{array}$ \\
\hline 01 & $1979-80$ to $1989-90$ & $\begin{array}{l}\text { English - Text and } \\
\text { Commercial } \\
\text { Correspondence }\end{array}$ & $\begin{array}{l}\text { Teaching English Language \& } \\
\text { Literary Text }\end{array}$ \\
\hline 02 & $1990-91$ to $1999-2000$ & $\begin{array}{l}\text { English - Text and } \\
\text { Commercial } \\
\text { Correspondence }\end{array}$ & $\begin{array}{l}\text { Teaching English Language \& } \\
\text { Literary Text }\end{array}$ \\
\hline 03 & $2000-01$ to $2007-08$ & English & $\begin{array}{l}\text { Teaching English Language \& } \\
\text { Literary Text }\end{array}$ \\
\hline 04 & $2008-09$ to $2010-11$ & $\begin{array}{l}\text { Business } \\
\text { Communication }\end{array}$ & $\begin{array}{l}\text { Teaching of English for Specific } \\
\text { Purposes }\end{array}$ \\
\hline 05 & $2011-2012$ & $\begin{array}{l}\text { Business English and } \\
\text { Communication }\end{array}$ & $\begin{array}{l}\text { Teaching of English for Specific } \\
\text { Purposes and of Communication } \\
\text { Skills }\end{array}$ \\
\hline 06 & $2012-13$ to $2018-19$ & $\begin{array}{l}\text { Sem - I: Business } \\
\text { English and } \\
\text { Communication-I } \\
\text { Sem - II: Business } \\
\text { English and } \\
\text { Communication-II }\end{array}$ & $\begin{array}{l}\text { Developing Communication } \\
\text { Skills in English }\end{array}$ \\
\hline 07 & 2019-2020 till present & $\begin{array}{l}\text { Sem - I: Fundamentals } \\
\text { of English and } \\
\text { Communication } \\
\text { Sem - II: Developing }\end{array}$ & $\begin{array}{l}\text { English Language and } \\
\text { Communication } \\
\text { Developing Professional Skills } \\
\text { in English } \\
\text { Developing Soft skills }\end{array}$ \\
\hline
\end{tabular}




\begin{tabular}{|l|l|l|l|}
\hline & $\begin{array}{l}\text { Communication Skills in } \\
\text { English }\end{array}$ & Developing Employability Skills \\
\hline
\end{tabular}

It is revealed from the above table (1979-80 to 2019-20) that there is a whole shift from the "Central Design" (1979-80 - 2010-11) approach to "Forward Design" (2011-12 - 2018-19) approach, then to "Backward Design" (2019-2020 onwards) can be seen through the analysis present below:

1979-80 to 1989-90 - the subject "English - Text and Commercial Correspondence" was hardly communicative in nature. The emphasis was more on Writing Skills leaving no space of developing LSRW. The contents of the syllabus are not drawn and listed in the official copy of syllabus approved by the Board of Studies and the Faculty Board of the Faculty. There was not a single text (textbook) prescribed in the syllabus with the absolute freedom being given to the teacher to make a (personal) choice. Moreover, the material and references of the prescribed texts were not a part of the designed syllabus. The syllabus was divided into two sections focusing on essay type questions from selected prose in one section and the commerce related correspondence in the other with pre-decided marking system. The prescribed syllabus seems to be based on the approach of "Central Design" where the list of topics are provided by the teachers to the students leaving very little space to explore and contextualise it in their life and career. The contents of the syllabus remained unchanged during the academic years 1990-91 to 1999-2000.

The beginning of the $21^{\text {st }}$ Century was the period where teaching language through GrammarTranslation Method was very prevalent in India, especially in Gujarat which is reflected in the contents of the syllabus offered. A major change can be seen in the syllabus of the subject "English" from 2000-01 to 2007-08. The focus was shifted to developing grammar and vocabulary along with the writing skills. The syllabus was designed adopting "Central" approach and was categorised in six units. The preference was given to the teachers to select the materials for students leading to focus more on comprehensions, grammar and vocabulary rather than developing speaking skills.

The focus shifted to "Business Communication" from "English" from the academic year 2008-09 till 2010-11. With the focus being shifted to the teaching and learning of business communication the components of vocabulary, grammar and comprehension compressed in one unit. References were provided to the students but, the objectives of the syllabus were not clearly stated. As commerce students, it was very important for the students to acquire Communication Skills, however the 
curriculum offered theoretical knowledge of the concepts of business communication making the syllabus monotonous.

The academic year 2011-2012, was a trial phase to introduce Semester System in the universities of Gujarat, especially in the Maharaja Sayajirao University of Baroda. Semester System was introduced to relieve the students from the age old monotonous practice of teaching and learning, a characteristic feature of extensive annual pattern of teaching and testing. The syllabus in the semester system was designed according to the students' need. The shift from "Centered Design" to "Forward Design" can be clearly noticed, providing comprehensive and evolved contents of the syllabi, materials and references to the students. However, the curriculum designed provided little space to develop English Language Skills. The syllabus 2011-12 was provided to the students only for one year as a part of the pilot project.

From the academic year 2012-13, CBCS was introduced in the Faculty of Commerce, the Maharaja Sayajirao University of Baroda. Choice Based Credit System (CBCS) in Higher Education aims at the holistic of the students providing them to choose the courses of their own choice from the given or prescribed subjects based on the Cafeteria policy. The courses in a programme are divided into three kinds: Core course i.e. the main subject and a compulsory requirement of a programme; Elective course is a complementary course which is intended to enrich the study of core subjects, allowing students to specialize in one or more branches of the subject area; and last, Foundation Courses which are of two kinds: Elective Foundation which focuses on Value Education and Compulsory Foundation i.e. English (on which the researcher focuses on in this research study). The prescribed syllabus seems to be based on the approach of "Forward Design" where the objectives, list of topics with sources are provided by the teachers to the students.

From the academic year 2019-2020, the new syllabus has been introduced to the students of Bachelors of Commerce programme. "The book addresses the linguistic and communicative needs of the students through a theory-practice emphasis and case studies method to equip them and enhance their communication skills..." (Preface, pg. vii- Fundamentals of Language and Communication). The previous book, though it was theoretical and skill based, a lot of time had to be spent in explaining the concepts. The case studies in the present book allow scope to discuss many things such as listening-speaking activities, presentation skills, etc. in the classrooms. The syllabus is based on the approach of "Backward Design". The syllabus has been redesigned with the specific objective 
of empowering the students with requisite skill sets to facilitate opportunities for higher studies and employment. It inculcates their communicative tendencies with the help of language. With a more holistic approach than the previous syllabus, the textbooks are introduced to various skills like referencing, note-taking, note-making, internet online resources, etc. The students are introduced to the basic history of English language and different dialects like American, British, Australian and India. Alongside LSRW, the textbooks also focus on grammar and vocabulary skills.

\section{Conclusion}

The Maharaja Sayajirao University has its internal review and feedback system which provides a platform to review the curriculum, make changes and improvements increasing the ease of the student movement from academia to industry, from campus to corporate. Thus, by implementing Outcome Based Curriculum Framework at UG level, the university provides both professional skills as well as all round qualities which must fulfil the growing demands of the $21^{\text {st }}$ Century such as communication skills, critical thinking, problem solving, analytical reasoning, etc.

$* * * * * * *$

\section{Primary Archival Sources}

\begin{tabular}{|l|l|}
\hline \multicolumn{1}{|c|}{$\begin{array}{c}\text { Academic } \\
\text { Years }\end{array}$} & \multicolumn{1}{c|}{ Retrieved From } \\
\hline $1979-80$ to $1989-90$ & Annual Prospectus for B.Com (1979-80) \\
\hline $1990-91$ to $1999-2000$ & Annual Prospectus for B.Com (1990-91) \\
\hline $2000-01$ to $2007-08$ & Annual Prospectus for B.Com (2000-01) \\
\hline $2008-09$ to $2010-11$ & Annual Prospectus for B.Com (2008-09) \\
\hline $2011-2012$ & Annual Prospectus for B.Com (2011-12) Sem-I \\
\hline $2011-2012$ & Annual Prospectus for B.Com (2011-12) Sem-II \\
\hline $2012-13$ to 2018-19 & Annual Prospectus for B.Com (2012-13) Sem-I \\
\hline $2012-13$ to 2018-19 & Annual Prospectus for B.Com (2012-13) Sem-II \\
\hline $2019-2020$ till present & Annual Prospectus for B.Com (2019-20) Sem-I \\
\hline $2019-2020$ till present & Annual Prospectus for B.Com (2019-20) Sem-II \\
\hline
\end{tabular}


Towards Excellence: An Indexed, Refereed \& Peer Reviewed Journal of Higher Education / Prof. Hitesh Raviya \& Ms. Deepali Shahdadpuri / Page 544-555

\section{Works Cited}

Dayal, Sheba R. "English Language Learning in the ESP Context: An Indian Experiment”. Language in India Journal vol. 5, August 08, 2005. Print.

Jafre, Z.A, and Rany Sam. "Factors Causes Students Low English Language Learning: A Case Study in the National University of Laos". English in Education, January 2013. Print.

“Learning Outcomes Based Curriculum Framework (LOCF)". May 2019. https://www.ugc.ac.in /pdf news /7357775 Public

Notice_LOCF.pdf?fbclid=IwAR1s6Zd96V0j_ruByyLy7wmxvvzuxi qwnP1Qg XLB3 rt3JZ8v1Am_JCmq0Y. Accessed on January, 242021.

McArthur, Tom (Ed.). The Oxford Companion to English Language. Oxford and New York: Oxford University Press, 1992. Print.

Rahman, Nor Haslynda A. From Curriculum Framework to Classroom Practice: An evaluation of the English Primary Curriculum in Malaysia. University of York, 2014. Print.

Richards, J. C. Language Curriculum Development. University of Hawaii, 1985. Print.

Taba, Hilda. Curriculum Development: Theory and Practice. New York: Harcourt Brace and World. 1962. Print.

Tilak, Jandhyala B.G. Higher Education in India: In Search of Equality, Quality and Quantity. New Delhi: Orient Blackswan, 2013. Print.

“Quality Improvement Programme”, 2018. https://www.ugc.ac.in/pdfnews/9675407_Public-NoticeLOCF 2018.pdf. Accessed on December 10, 2020.

Wiggins G., McTighe J. Understanding by Design: A Framework for Effecting Curricular Development and Assessment. Alexandria, UA Association for Supervision and Curriculum Development. 2006. Print.

\section{Prof Hitesh D Raviya \\ Head, Department of English,} The Maharaja Sayajirao University of Baroda, Vadodara Email : hitesh.raviya-eng@msubaroda.ac.in \&

Ms. Deepali Dinesh Shahdadpuri

Ph.D. Research Scholar, Faculty of Arts

The Maharaja Sayajirao University of Baroda, Vadodara

Email : deepali.s-engcomm@msubaroda.ac.in 